\title{
Teleological Trajectory of Subjection: A Critique of Marlovian Heroes
}

\section{Sukhdev SINGH' ${ }^{1}$}

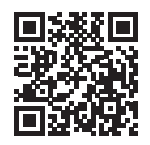

'Dr., National Institute of Technology Patna, Department of Humanities \& Social Sciences, Patna, India

\section{ORCID: S.S. 0000-0002-4952-9541}

\section{Corresponding author:}

Sukhdev SINGH,

National Institute of Technology Patna, Department of Humanities \& Social

Sciences, Patna, India

E-mail:dr.singhs@outlook.com

\section{Submitted: 19.02 .2020}

Revision Requested: 05.04.2020

Last Revision Received: 14.06 .2020

Accepted: 24.07 .2020

Citation: Singh, S. (2020). Teleological trajectory of subjection: A critique of Marlovian heroes. Litera, 30(2), 385-406. https://doi.org/10.26650/LITERA2020-0040

\begin{abstract}
One might view Christopher Marlowe's heroes such as Tamburlaine, Barabas, Edward II and Doctor Faustus in terms of individuals who capably transgress the boundaries within which they are located. War for Tamburlaine; gold for Barabas; philia, which is defined as love or friendship between an older and a young man, for Edward II; and the knowledge of good and evil for Doctor Faustus are those mediums by which they apparently subjectivise themselves. This study analyses their subjectivities by posing a fundamental question: do they form their individuality on their own or is it a matter of a paradigm of divine providence? The paradigm of divine providence might be equivalent to a structure of power. This study has recourse to what might be termed the Foucauldian teleology, which is based on some of Michel Foucault's fundamental ideas. In other words, in order to present a critique of Marlovian heroes, this study has recourse to the Foucauldian teleology which involves various mechanisms of control to subjectivise ordinary people in accordance with the state or the structures of power. Thus, the Marlovian heroes are kept in a centripetal motion, which might be viewed in terms of a trajectory of subjection that brings them out from the periphery and carries them to the centre for subjectivisation, within and by the structures of power. This study utilises the textual evidence from prologues and epilogues of some of Christopher Marlowe's plays that may indicate such a process of subjectivisation.
\end{abstract}

Keywords: Christopher Marlowe, Michel Foucault, The Jew of Malta, Edward II, Doctor Faustus 


\section{Introduction}

Christopher Marlowe was born in 1564, led quite a controversial life and died in mysterious circumstances. His major plays include: Tamburlaine the Great I \& II (1587), The Jew of Malta (1590), Edward II (1592) and Doctor Faustus (1592). Marlowe's eponymous heroes do not belong to a category of mainstream protagonists. Tamburlaine is a 'shepherd' by birth, and is referred to by different people as base-born and a fox. Barabas is a 'Jew', and he is addressed as an infidel and a villain. Edward II is a'homosexual' king, and he is called a sweet prince, unnatural and misgoverned king. Doctor Faustus is a 'necromancer', and, besides being called doctor, he is also referred to as a conjuror and damned.

In the case of Tamburlaine, it might be noteworthy that these epithets, firstly, indicate his ignoble descent. Secondly, they characterise him in the erstwhile time while he is on the move to be the ruler of the world. In Barabas's case, these epithets, firstly, portray him in religious terms. Secondly, he is known as good or bad, which is contingent upon his actions vis-à-vis other people. Edward II is viewed, in accordance with these epithets, firstly, as a mild natured person. Secondly, he is considered in idealist terms. Thirdly, he is evaluated with respect to his relationship with Gaveston. Lastly, Edward II is seen as an inadequate king, who is not interested in the administrative responsibilities ascribed to a king. In the case of Doctor Faustus, these epithets are a perceptible sign of a movement or change in him from being an intellectual to a sacrilegious magician or conjurer due to which he finally degenerates and is damned.

Irving Ribner (1953) takes recourse to Collingwood's terms 'humanism' and 'substantialism' while explaining Tamburlaine the Great and the idea of history. Concerning humanism, he points out:

There is nothing of Christian recognition of sin and repentance before death. If there is any tragedy in the play it is in the tragedy of man himself, the recognition that all men, no matter how great or noble, must inevitably die...And Tamburlaine is a hero not because of any Christian virtues, but because of a Machiavellian virtù which enables him to master fortune and win success in his enterprises. The theme of the play is a glorification of virtù, and this theme places Tamburlaine outside the Christian world of divine providence which rewards man for good and punishes for evil. As 
history it belongs in the A-Christian world of Machiavelli which considers not what should be but what is, and which does not study the path to virtue, but rather the path to success. (pp. 257-58)

In other words, Marlovian heroes, especially Tamburlaine, Barabas and Faustus, extricate themselves from the Christian paradigm of divine providence. According to this paradigm, God as the sovereign creator causes events, makes history and produces tractable human beings whom he can change from evil to good. God is the ultimate authority, thereby creating an equivalence between God and the Foucauldian analysis of the state and its various apparatuses, which have been discussed below, would not be unwise. The Marlovian heroes, conversely, assert that the events of history are a product of man's actions and will power, not divine intention. Apparently, it is a plausible argument, but a close examination of different parts of Marlowe's plays reveals otherwise.

One might perceive the equivalence between God and the state through Michel Foucault's (2003) analysis of intricate cobwebs of control over the individual. The control might be initiated, first, through the process of medicalisation of private space of the family in which the focus is on, especially, the male children's sexuality. Based on the discursive practices in the 1720s, which included texts or manuals of exhortation, advice and injunctions, Foucault (2003) discusses the infantile onanism, which is a tendency of masturbation in male children (p. 238). He reveals the belief in a link between the male onanist's masturbatory practice and physical illness of which the outcome is death, thereby leading to physical proximity between the onanist and the parents who turn themselves into watchdogs of the onanist's body. This control over the body, later on, gives way to the medical intervention represented by the doctor, thereby replacing the familial watchdogs by the medical one.

Foucault seems to view the doctor-onanist relationship as a means to ethical and physical or sexual control. It turns the family's private problem, which is its male children's onanism practice, into a medical need. He terms it a field of "medico-familial mesh" that is ethical as well pathological within which "sexual conduct becomes an object of control, coercion, examination, judgement and intervention" (Foucault, 2003, p. 254).

The second means of control over the individual, which lets one perceive the equivalence between God and the state, is through Foucault's (1988) discussion of the 
police. The word police entails a number of meanings. The Latin politia and a cluster of Greek words such as politeia, politēs and polis mean citizenship, government, citizen and city state. In other words, it refers to something that functions in relation to the citizen, city and the government. He focuses on the late fifteenth and sixteenth to the end of nineteenth centuries during which the police signify public order. In accordance with his genealogical analysis, the police are viewed in terms of "specific techniques" by which the state governs individuals as utility, that is, individuals who can be used by or expended for the state (Foucault, 1988, p. 154).

According to Foucault (1988), the police-as-specific-techniques are used in three forms: dream or utopia, practice or rules for real institutions and academic discipline. They cover quite a wide area: the education of children, care of the unfortunate and the destitute; the private property market, religion, moral conduct of the individual and the factory worker. He notes the functionality of the police:

The task of the police was to foster civil respect and the public morality... In a word, what the police see to is a live, active and productive man. [W] ith this new police state the government begins to deal with individuals, not only according to their juridical status but as men, as working, trading, living beings. (pp. 154-56)

In other words, it is the individuals' life or society in toto that is the object of the police. He is not much concerned with how the police govern according to the law. He rather argues for "a specific, a permanent, and a positive intervention" by the police in the individuals' behaviour (Foucault, 1988, p. 159). Thus, the real problem might not be countable anti-social elements with which the police may have to deal. It might be, in fact, a multitude of people that the police have to contain.

The nature of control within the familial, medical and the policing space appears to be interventionist in the Foucauldian worldview. It might be argued that this intervention leads individuals to subjectivisation at the behest of the state. Just like the Christian paradigm of divine providence, from which Marlovian heroes capably extricate themselves, it seems through Foucauldian analysis that the state also assumes the sovereign creator's role and constructs tractable subjects. The modus operandi in this respect might be hypothetically explained: the individuals are kept in a centripetal motion, that is, they are moved from their private periphery to the 
open and public centre. In other words, the individuals are placed on a trajectory of subjection through the intricate cobwebs of control that finally takes them to the centre for subjectivisation.

The equivalence between the Christian paradigm of divine providence and Foucauldian analysis might indicate towards teleology vis-à-vis the individual. For lack of a better term, it could be called Foucauldian teleology. The entire journey of the individual, from birth to death and from the periphery to the centre, in accordance with this idea of teleology seems to have been predetermined through the intricate cobwebs of control.

As referred to above, apparently, Marlovian heroes aberrate from the rigid norms of their societies by rejecting the predetermined roles and categorisations or identifications that have been recognised as the lineage of Tamburlaine, religion in the case of Barabas, sexual preference and the societal or royal responsibilities of Edward II and the knowledge of Doctor Faustus. Quite unlike what happens with the individual in accordance with Foucauldian teleology, Marlovian heroes, apparently, aberrate from the trajectory of subjection that leads them to subjectivisation in accordance with the state. That is, they seem to grapple with a priori world bifurcated into good and evil, and thereby climb up the ladder of success in their respective preoccupations by Machiavellian virtù, or their skill, ingenuity, and ability (Bondanella, 2005, p. xii). In short, Marlovian heroes appear to capably move out of the predetermined space allotted to them on the margins of their society to occupy the centre stage. Nevertheless, they are not led by the nose by God or the state in their endeavours.

According to Ribner (1953), Collingwood's substantialism is a derivation of metaphysics that defines substance, for instance, human beings and countries, in the sense of constancy and, therefore, it can be known (p. 260). In other words, it has a fixed form and does not change. On the contrary, the subject matter of history is composed of temporal and transitory events. History, in this sense, cannot be knowable. In short, history is quite unlike the "substantial, unchanging in form, and thus knowable" individuals such as Tamburlaine and Barabas (Ribner, 1953, p. 261).

As a result of such theorisation, which proposes a binary opposition between history and human beings on the basis that the former is merely a flow of changing events and the latter are substantial, one might have Marlovian heroes disjointed from the 
powerful flux of history or social process. Thus, they might be recognised as subjects without history. In other words, one might understand that history does not influence the construction of human beings. They, in short, enter endless identity crises and thereby remain nameless. Further, one might have them turned into atemporal or transcendental subjects who disregard historical finitude and social process that are instrumental in the construction of human beings. The argument that places them out of history and society, thereby turning them into atemporal, transcendental and ahistorical subjects, is largely fallacious. Despite the dissent of the Marlovian heroes, as it is amply corroborated in Marlowe's plays, they can escape neither the Christian paradigm of divine providence or history nor Foucauldian teleology or social processes.

\section{Aim and Methodology}

The aim of this study is to present a critique of Christopher Marlowe's heroes by finding out how they have been subjectivised. As indicated above, Marlovian heroes are apparently transgressive. That is, they transgress the limitations in society and construct themselves on their own. Thus, Marlovian heroes are apparently self-made men. The aim of this study is to present a critique of the idea of the self-made individual. The methodology is to find out textual suggestions from some of these plays written by Marlowe that go against the idea of the self-made individual. Another part of the methodology is some of Michel Foucault's ideas that might build and be termed Foucauldian teleology, which involves various mechanisms of control to subjectivise ordinary people in accordance with the state or the structures of power.

\section{Findings}

Since this study focuses on the four Marlovian heroes, its findings have been placed under four fundamental points. The first is that war is a pocket, or area, of power within which Tamburlaine is subjectivised. The second is that insofar as Barabas is concerned, gold is an essentialising factor. It also functions just as Ferneze's politics does. That is, the former's gold is equal to the latter's politics. The third fundamental point is about the idea of philia, or love or friendship between an older and a young man, by which Edward II is bound to Gaveston, thereby getting himself subjectivised. The fourth point is about Doctor Faustus' knowledge of good and evil and how it subjectivises him. Four of these fundamental points have been discussed below in detail. 


\section{War as a Pocket of Power and Tamburlaine}

Tamburlaine's engagement in wars, which entail violence, consequent victories and charting new territories are an obvious sign of his inextricable presence and participation in the historical process or convention of enlarging one's territory by waging wars. Mycetes commands Theridamas to war with Tamburlaine:

Go, stout Theridamas, thy words are swords, And with thy looks thou conquerest all thy foes.

I long to see thee back return from thence, That I may view these milk-white steeds of mine All loaden with the heads of killed men, And from their knees even to their hoofs below Besmeared with blood that makes a dainty show. (Marlowe, 1940, 1.1.73-80)

These lines are indicative of war or killing as considered a prominent medium of display of one's power as well as a spectacle to behold and relish. It might also be a type of ritual that they perform. After two lines, when Mycetes sees Menaphon's reluctance to assist Theridamas, he asks: "Ah, Menaphon, why stayest thou thus behind / When other men press forward for renown?" (Marlowe, 1940, 1.1.83-4). Christopher Marlowe conceives war, in these lines, as a way whereby the participants record themselves and become famous in history.

War is an approved and prescribed activity in society. Following Foucauldian teleology, it might be argued that Tamburlaine, Mycetes and others are in a centripetal motion, whereby the centre or destination is war. Does it mean they are moving towards what might be called agentification? Kathryn Schwarz (2013) disagrees as she finds all actions are errant that one realises later (p. 194). Through violence, which war entails, one brings end into focus and gives a shape and definiteness to life (Greenblatt, 1980, p. 197). It might also provide one with such a space wherein people like Tamburlaine "search for a masculine identity" irrespective of consequences (Huebert, 2003, p. 23). Thus, war exceeds the status accorded to it above as a ritual and becomes a medium of ennobling one's self. One might argue that war is a pocket of power within which Tamburlaine and others are subjectivised. 
Georges Bataille (2001) discusses a primordial form of war vis-à-vis the Christian commandment of "Thou shalt not kill" (p. 63). Despite prohibition, the commandment does leave some space for killing, for instance, in duel, feud and war (Bataille, 2001, p. 72). In other words, there are permitted exceptions to the taboo of killing in Christianity that clearly bans the killing of human beings. Bataille (2001) holds:

Primitive war is rather like a holiday, a feast day, and even modern war almost always has some of this paradoxical similarity. The taste for showy and magnificent war dress goes very far back, for originally war seemed a luxury. It was no attempt to increase the peoples' or rulers' riches by conquest: it was an aggressive and extravagant exuberance. (p. 76)

Although such an argument decontextualises war from Marlowe's play, one might yet argue that for most of Tamburlaine's opponents, but not for Tamburlaine, war is an affordable luxury. They wonder how a person who is not even eligible to wage a war can afford it. He does not kill people unnecessarily, nor does he seem to be a person to wage war just for a show or extravagance. The path to war is an upward trajectory, or like a ladder, for him to climb up the social scale in order to change his status or subjectivise himself anew "through the irreverent overthrow of inherited structures of deference and identity" (Engle, 2013, p. 202).

However, there is only one point that discredits and excludes Tamburlaine from the discourse of war: his lineage. None of his opponents desist from referring to his humble background and ignoble origin. It is not Tamburlaine, or war, who is a thorn in their flesh. His lineage is the real bone of contention for his opponents. Therefore, Cosroe, who is Mycetes's younger brother and has conspired against him with Tamburlaine, is aghast when he is double-crossed by Tamburlaine: "What means this devilish shepherd, to aspire / With such a giantly presumption" (Marlowe, Tamburlaine I, 1940 , 2.6.1-2). He might have compromised with being double-crossed, but a shepherd snatching the crown that he has planned to put on his head is completely unacceptable to him.

In their world, not everyone can be coronated. In spite of war as a valid pocket of power within which the process of subjectivisation occurs, not everybody can partake in war. In order to wage a war, one must be of noble origin. Tamburlaine is aware of his social status and identity:"I am a lord, for so my deeds shall prove, / And yet a shepherd 
by my parentage" (Marlowe, 1940, 1.2.34-5). On the one hand, due to his status as a shepherd and his royal and noble opponents, he gets disqualified and prohibited from becoming a part of discourse or convention of war in accordance with the values of his society. In other words, Tamburlaine's royal and noble opponents and conventions of his time attempt to freeze his centripetal motion. On the other, it is only through his actions in war, whose foundations are his "invincible army and an unshakable will", that he ennobles his self (Huebert, 2003, p. 27).

War, even though he is not eligible to participate in it, is a pocket of power wherein "fates and oracles [of] heaven have sworn / To royalise the deeds of Tamburlaine" (Marlowe, 1940, 2.3.7-8). In other words, he is capable of reworking his identity after every victory in war, and thereby capable of moving out from the margins of his society to its centre.

\section{Barabas' Gold is Equal to Ferneze's Politics}

Dena Goldberg (1992) discusses Marlowe as an invert, somebody who turns things inside out or upside down, with respect to the ways he uses material for his plays, for instance, the stereotype of the Jews as ritual sacrificers (pp. 235-36). She contends:

Even as he [Marlowe] uses the mythic material, Marlowe plays with it, diluting its polarities, demystifying its ritual centre....Barabas is a travesty of a suffering hero or Christ, even to the extent of a faked death and resurrection....What I am contending, rather, is that in The Jew of Malta Marlowe's corrosive irony has the effect of debunking myth and ritual, both orthodox and popular, especially as it is used to explain the existence of suffering and evil....And the myth and ritual invented to legitimise and glorify human suffering is reduced to its political functions. (p. 237)

Barabas' first meeting with the Governor of Malta might corroborate how the playwright inverts the aforesaid stereotype. Three decrees are read out to Barabas and his fellow Jews:

First, the tribute money of the Turks shall all be levied amongst the Jews, and each of them to pay one half of his estate....

Second, he that denies to pay, shall straight become a Christian.... 
Lastly, he that denies this, shall absolutely lose all he has.

(Marlowe, 1965, 1.2.69, 1.2.72-4)

Needless to say, the Christian majority of Malta, represented by Ferneze, the Governor of Malta, is salvaged at the expense of the Jew minority community of Malta, represented by Barabas. They are utterly exploited and sacrificed.

Goldberg (1992) derives the concept of sacrifice from René Girard who has argued against the anthropological standpoint that places sacrifice within the rites of fructification and expiation on the part of the individual or the entire community (pp. 239-40). She explains that according to him it

is a mechanism by which the community attempts to save itself from its own violence by inflicting that violence on a scapegoat....What makes people 'sacrificeable' is their marginality, the fact that they are not fully integrated into the community....There is nothing mysterious about this choice of marginal victims: it is dictated by the practical consideration that the suffering of a person who is not truly bonded into the community will not bring about retaliation in the form of further violence. (p. 240)

In other words, according to Girard, sacrifice is a political phenomenon, and she adds that Marlowe links it with its inseparable part, that is, economic (Goldberg, 1992, p. 243). One might view Ferneze as the representative of politics and Barabas as a representative of economics.

At this juncture, Foucauldian (1990) theorisation of one of the three domains or techniques of the self, which is economics or the art of commanding, managing or ruling, might be relevant (pp. 153-54). It is asserted, especially in the context of a married man, that "manage[ment of] the oikos [or household] is to command, and being in charge of the household is not different from the power that is to be exercised in the city" (Foucault, 1990, p. 153). It is a clear indication of the association or relationship between the inside and the outside domains of the household and power. Malta as oikos is also managed by Barabas as it is by Ferneze. Political and monetary powers are on an equal footing. Thus, both Barabas and Ferneze should be held equally responsible for their oikos. However, due to primacy accorded to material acquisition, one might have a simulated antagonism between politics and economics (Greenblatt, 1980, p. 204). 
As the image of the Jew as a sacrificer has been inverted above, the image of the Christian as somebody who has a compassionate heart is also cancelled. In short, it would be credulous to strictly categorise Ferneze as good and Barabas as bad, since they are nothing but "brothers under the skin" (Goldberg, 1992, p. 239). In other words, politics and economics are complementary and in consonance with each other. If there is any dissonance between the two, it must be either a show or eradicated only if the objective is a smooth governance of the people. Moreover, Barabas' act of defiance against confiscation of his property may constitute "an emblem of authority" vis-à-vis Ferneze's (Huebert, 2003, pp. 25-6).

\section{Edward II's Philia for Gaveston}

Queen Isabella and the nobility at the court of King Edward II are worried about or annoyed with him. She informs Mortimer Junior when he accosted and asked her where she was going:

Unto the forrest gentle Mortimer,

To live in greefe and balefull discontent,

For now my lord the king regardes me not,

But dotes upon the love of Gaveston.

He claps his cheeks, and hanges about his neck,

Smiles in his face, and whispers in his eares,

And when I come, he frownes, as who should say,

'Go whether thou wilt seeing I have Gaveston.'

(Marlowe, 1981, 1.2.47-54)

Apparently, for the nobles also, Gaveston with whom the King is openly obsessed is a thorn in their flesh. Marlowe is unambiguous about why they are discontented with Edward II and Gaveston. Isabella is side lined as her husband prefers Gaveston more than his wife. She is prohibited to have access to her husband when Gaveston is in England. Even if Gaveston is banished, she is accused of creating hurdles between their confluence and his beau's banishment. Therefore, she is kept away. Such a maltreatment, especially, when she is placed vis-à-vis Gaveston, meted out to her sabotages her royal authority, and it disenfranchises her of marital and sexual rights over her husband. 
In other words, Gaveston's existence in relation to Edward II is detrimental to her private and public identities both as a wife or sexual partner and as a royal Queen in England. Thus, she has all the reasons to be circumspect of her husband's lover.

Gaveston's low origin or social status is referred to time and again in the form of epithets, for instance, Lancaster says:"My lord, why do you thus incense your peeres, /That naturally would love and honour you, / But for that base and obscure Gaveston?" (Marlowe, 1981, 1.1.98-100). Mortimer Junior also says: "Thou villaine, wherefore talkes thou of a king, / That hardly art a gentleman by birth?" (Marlowe, 1981, 1.4.278). It is obvious that the entire nobility objects to Edward II as he is fond of and mindlessly confers political or noble titles on his lover, who is of ignoble origin, with a lavish hand.

In other words, Gaveston is a threat to the nobility with regard to his ignoble origin as well as profession. He tarnishes their birth and foils their political expediency. As it is in Isabella's case, in their case too, Gaveston jeopardises their private and public identities. Therefore, from the perspective of the nobility, his proscription is compulsory and the most sought-after option available to them.

However, in an interesting argument Viviana Comensoli (1993) rejects the proposition that is built upon the factors of lineage of Gaveston, his political expediency and Edward II's inadequacy in his public as well as personal domains (pp. 175-76). She refers to Holinshed, Fabyan and Stow's historiography covering the reign of, historical, not dramatic, Edward II in which they have dealt with homophobia and homosexuality quite implicitly (Comensoli, 1993, pp. 177-79). She argues that it is "Marlowe's deliberate distortions" of such historiography that in the dramatic version of Edward II's homosexual relationship, which had invited repression and eventually led to deposition of Edward II from the patriarchal, heterosexual and homophobic society of the historical king, is rendered almost transparent and explicit (Comensoli, 1993, p. 177).

She argues further:

Mortimer, at least ostensibly, is heterosexual like the father. Yet his love relationship with Queen Isabella always takes second place to his desire to overthrow Gaveston, suggesting, I will argue, an unconscious fear of his own homoerotic impulses. Mortimer's latent homosexuality is suggested 
by two important ahistorical developments: his preoccupation with and contempt for Gaveston's deviant masculinity, which the barons equate with baseness; and his collusion with Isabella in plotting Gaveston's death. (p. 187)

In other words, Mortimer Junior is apparently heterosexual, but a latent homosexual, because of which he qualifies to represent the patriarchal structure of society where symbolic law or the law of the father is the norm. Therefore, if people like Edward II and Gaveston infringe it, the structure will automatically accord legitimacy to Mortimer in order to chastise such deviancy. In short, the very rhetoric of the patriarchal norm not only legitimises nobles, led by Mortimer Junior, but also becomes a façade behind which the structure hides its homophobia for flagrant homosexuals as well as the homosexuality of those who abide by the norm.

Therefore, Comensoli (1993) advises:

By accepting at face value the barons' deposition of Edward II strictly on the grounds of political incompetence, as has been the general practice in Marlowe scholarship, we are thus ignoring the subversive implications of Marlowe's interrogation of official history. (p. 199)

That is, Marlowe's distortion or dramatisation of the historical Edward Il's life, as recorded by the above mentioned historians, examines historiography and locates the origin of the entire political crisis in homophobia and homosexuality.

The homosexual bond between Edward II and Gaveston is incontrovertible and fairly confirmed. Nevertheless, there are a couple of loopholes by which an argument based on homosexuality considered and treated as abnormal or flouting the norm leading to political unrest, especially in Marlowe's time, might be denounced.

Firstly, Gaveston is a highly ambitious man. To achieve his goals, he manipulates his relationship of love with Edward II and remains an utterly selfish man (Huebert, 2003, p. 30). He knows how exactly the king can be overpowered:

Do: these are not men for me, I must have wanton poets, pleasant wits, 
Musitians, that with touching of a string

May draw the pliant king which way I please: Musicke and poetrie is his high delight,

Therefore ile have Italian maskes by night,

Sweete speeches, comedies, and pleasing shows,

....Such things as these best please his majestie.

(Marlowe, 1981, 1.1.49-55, 1.1.69)

His aspirations, manipulation and methodology of overpowering the king are clear in these lines. The nobles are also as ambitious as their opponent is. The main difference lies in the operation of power over and the methodology of generation of consent of Edward II. They always threaten him to forsake Gaveston or he will have to face a violent revolt that might result in either his deposition or brutal killing. That is, the nobles' methodology of generation of consent is coercion. It is only the intimidating and glaring sword, which ultimately is instrumental in claiming the king's life but not his consent, that speaks for Mortimer Junior. In Gaveston's case, homosexuality is not only a relationship to sexually consume each other, it is also a very efficient tool, which works through small revelries and entertaining shows, for generation of Edward II's consent to submit completely to him.

Secondly, the reason behind the nobles' disappointment, which doubtless includes Mortimer's too, and such a political upheaval in Edward II's reign are not due to the king being homosexually related to another person:

The mightiest of kings have had their minions,

Great Alexander loved Ephestion,

The conquering Hercules for Hilas wept,

And for Patroclus sterne Achillis droopt:

And not kings onelie, but the wisest men,

The Romaine Tullie loved Octavious,

Grave Socrates, wilde Alcibiades.

(Marlowe, 1981, 1.4.389-95)

For a male to have a relationship with another male, as cited above, has been a long tradition. This tradition might be recognised in terms of Foucauldian philia, which is translated as 'love' or 'friendship', that is, "an affinity of character and mode of life, a 
sharing of thoughts and existence, mutual benevolence" (Foucault, 1990, p. 201). The philia is a relationship between an older and a young male (Foucault, 1990, p. 195). The formation of the young male's self and status entirely depend on how the philia is conducted with his older counterpart. This philia might be the path that leads the young male to subjectivisation.

A man's philia for another man, in other words, is quite normal. Therefore, Edward II's philia for Gaveston might not disappoint the nobles. Their disappointment grows because of "one so baselie borne, / Should by his soveraignes favour grow so pert, / And riote it with the treasure of the realme, / While souldiers mutinie for want of paie" (Marlowe, $1981,1.4 .402-05)$. It is also because of "The king of France sets foote in Normandie" (Marlowe, 1981, 2.2.9). In other words, the reason behind the conflict between the king and the nobles is because the kingdom of Edward II is undergoing a financial crunch and a political challenge from France.

It is, in short, because of economic and political problems, which have marred England, that the nobles are upset with the king. Why Gaveston incurs their wrath and criticism and finally death might not be because of his philia with Edward II. Besides the fact that personally he is a blot on the nobility because of his ability to overpower the king in spite of his ignoble origins, the nobles somehow consider him the main source of their king's diversion from the economic and political crises of the state.

One might argue that Edward II, and Gaveston too, is an economic and political deviant, not sexual. As it has been corroborated on the basis of textual evidence above, he participates in a very long tradition of philia, which might be viewed as homosexuality in today's world, and maintains the philia with Gaveston until he is mercilessly killed. Homophobia, as discussed above through Comensoli, might hardly find any space to occupy in the Marlovian society where, because of the theatre's influence, it is quite normal for a man to have philia with another man.

\section{Good and Evil versus Doctor Faustus}

In Doctor Faustus, Christopher Marlowe presents a clear-cut contrast between good and evil characters. For instance, there are a number of good people and good angels: his scholar friends, the old man, his servant Wagner, and the Good Angel. There are also a number of evil people and evil angels: his magician or necromancer friends, 
Valdes and Cornelius, Robin, and Lucifer, Belzebub, Mephistophilis, and Evil Angel. Such a distinction might refer to a monolithic world inhabited by those who are fossilised as either good or evil, that is, a traditional classification intended to make good people and characters remain forever good and virtuous, and evil to remain eternally damned.

After having conjured Mephistophilis, while Faustus asks him who he is, he introduces himself and other evil angels as "Unhappy spirits that fell with Lucifer, / Conspired against our God with Lucifer, / And are for ever damn'd with Lucifer" (Marlowe, 1940, 1.3.71-3). One cannot be more lucid than Mephistophilis in order to explain rigidity and immutability.

Conversely, there is the Old Man whose "faith is great" to such an extent that Mephistophilis "cannot touch his soul" even though they attempt to do so in order to turn him away from God (Marlowe, 1940, 5.1.78). In other words, Doctor Faustus inhabits a rigidly bifurcated world of good and evil in which once a human being has either chosen, of his or her own free will or otherwise, or commits a mistake to opt for evil, such an action remains irrevocable. Despite such predetermination, Marlowe creates Doctor Faustus as a site of fluidity and ambivalence. He might be both a "disappointing worldling" and a "multivalent figure", thereby constituting a "tragic selfhood" for himself (Engle, 2013, p. 210). Throughout the play, he eschews such preordained classification of subjectivisation into good or evil, thereby remaining neither completely good nor evil.

There are several reasons for it. Firstly, he remains through and through an academician. He has studied the valid branches of knowledge prevalent in his time. Knowledge is the prime building block of Doctor Faustus. Yet he has an exceptionally unbridled desire to study and learn more. This unbridled desire is due to having used up the valid knowledge (Greenblatt, 1980, p. 198). Therefore, he yearns for forbidden knowledge and eventually pursues it. However, there is another important reason why he chooses to go beyond the recommended boundary. He has studied Analytics, Economy, Physics, Law and Theology etc., yet he remains merely "Faustus, and a man" (Marlowe, 1940, 1.1.23). That is, the entire tradition of knowledge and wisdom is pointless if it cannot aid human beings in their survival. The valid knowledge does not promise to insure human life. Thus, Doctor Faustus' subjectivisation through valid knowledge is faulty, and thereby he must transgress this boundary. 
In other words, the state of human beings has not changed even though there is a great intellectual tradition. A human being is still vulnerable as he or she has been for ages. Therefore, it is judicious to reject the pursuit of such inefficient or inadequate intellectual tradition that cannot "make men to live eternally, / Or, being dead, raise them to life again" (Marlowe, 1940, 1.1.24). Is this rejection of academic establishment also to be viewed as an act of defiance against authority and his desire to know more? (Huebert, 2003, p. 38). Such defects, which he has detected in the system of knowledge, or apparent promise of necromancy to equip Doctor Faustus with power to raise the dead, are his rationale to opt for necromancy.

Secondly, one might view his interaction with Mephistophilis as inquisitive catechism in order to collect material or primary sources for research. After he has attained the status of "conjurer laureate", because he has finally conjured up the devil, he asks a series of questions (Marlowe, 1940, 1.3.32). Who is your lord, Lucifer? Was Lucifer not an angel once? How did Lucifer become the prince of devils? Where are you damned? How did you come out of hell? Does Lucifer tempt human beings to enlarge his kingdom? Do you feel pain like others? Where is hell? Why do you think that Faustus will be damned? Engle (2013) answers the last question by viewing Faustus's life as secular in which the thrust is on the temporal instead of the spiritual (p. 203).

These questions, it seems, have been asked to know the unknown. Whether some amount of veracity is attached or not to the answers that he gets from Mephistophilis, for Doctor Faustus hell is a fable and whatever the devil has told him is nothing but "trifles and mere old wives'tales" (Marlowe, 1940, 2.1.136). Does this indicate his genuine disbelief? (Huebert, 2003, p. 39). It is doubtless a flippantly made statement. Nevertheless, it does not diminish the chances to argue that he simply rejects Mephistophilis' answers, for instance, "where we are is hell" (Marlowe, 1940, 2.1.123).

Thirdly, whenever there are attempts on his part to go in the direction of evil, the Good Angel or the Old Man intervenes to admonish him not to opt for it. When he thinks of repenting, the devils prevent him. In other words, he is never allowed, or he is interrupted, to subjectivise himself. Doctor Faustus oscillates from good to evil and from evil to good throughout the play. 
However, Jonathan Dollimore (2004) argues:

Faustus is constituted by the very limiting structure which he transgresses and his transgression is both despite and because of that fact. God and Lucifer seem equally responsible in his final destruction, two supreme agents of power deeply antagonistic to each other yet temporarily cooperating in his demise. Faustus is indeed their subject, the site of their power struggle. (pp. 110-11)

Marlowe presents most of the things in dyads throughout Doctor Faustus. They are in binary opposition, for instance, good and bad people, Good and Evil Angels, the Old Man and Mephistophilis, and God and Lucifer etc. As argued by Dollimore (2004), God and Lucifer do collude against Doctor Faustus (p. 111). People represent them in perennial antagonism to each other and as vying to claim an individual. However, their opposition that the faithful believes in might be misleading. Moreover, Godly judgments remain insignificant vis-à-vis "intellectual framework" that Doctor Faustus has built (Engle, 2013, p. 206).

Dollimore (2004) suggests that "the most fundamental contradiction in Christian theology is reactivated: evil is of the essence of God's creation" (p. 117). Similar is the case with most other theologies in different parts of world. If God had created everything, He would surely have created Lucifer too who an angel once "and most dearly lov'd of God"(Marlowe, 1940, 1.3.66). At this point, Dollimore (2004) asks a pertinent question: "how is evil possible in a world created by an omnipotent God?" (p. 117). If evil is possible, it will be given birth by God Himself, otherwise there will be no evil.

\section{Discussion and Conclusion}

As the dyad constituted of antagonistic elements in Marlowe's Doctor Faustus, one finds another very important dyad. The first constituent of this dyad is the people that represent the establishment, for instance, different rulers and their states against Tamburlaine; the Governor of Malta and Malta itself against Barabas; the Queen, Mortimer and nobles and England against Edward II; and God, or good, and evil against Doctor Faustus. Marlovian heroes seem to occupy the second constituent of this dyad. Both the constituents of the dyad vie for prominence. However, it seems that the latter is overly eager. Most of the Marlovian heroes tenaciously aim for deification. This 
deification or subjectivisation might be equivalent to Stephen Greenblatt's (1980) selffashioning, especially, in an environment of opposition within which they are located (pp. 1-2).

Tamburlaine as a desiring machine of violence, which is incessantly in motion, produces the spoils in the form of male prisoners of war, women and, especially, crowns grabbed after each victory (Greenblatt, 1980, p. 195). These victories make him "a king" that is "half to be a God" (Marlowe, 1940, 2.5.56). For Barabas "Hermoso placer de los dineros", or beautiful pleasure of money, and nothing else, is of paramount importance (Marlowe, 1965, 2.1.63). Moreover, for him it is gold, not the Governor's office, that "serve[s] in peril of calamity / To ransom great kings from captivity" (Marlowe, 1965, 1.1.31-2). Therefore, he "must confess we [the Jews represented by Barabas] come not to be kings.... / Give us a peaceful rule; make Christians kings, / That thirst so much for principality" (Marlowe, 1965, 1.1.127, 1.1.132-33). Edward II is already a king, yet his deification or subjectivisation does not lie in being in charge of the royal command. His deification or subjectivisation happens after he has transmogrified his self into "another Gaveston" who loves the king "more than all the world" (Marlowe, 1981, 1.1.142, 1.4.77). It is magic and the world of necromancy, not the pursuit of the Holy Bible and God, that promises Doctor Faustus "a world of profit and delight, / Of power, of honour, of omnipotence" (Marlowe, 1940, 1.1.54-5). In short, being a"sound magician is a mighty god" (Marlowe, 1940, 1.1.63).

In other words, one might argue, besides the establishment in the above dyad, the Marlovian heroes, for instance, Tamburlaine can create docile subjects by the use of words only. They, for instance, Barabas and Edward II can save the lives of townsmen and exclusive individuals. Tamburlaine, Barabas, Edward II, and Doctor Faustus can destroy whoever comes to stop them from deification or subjectivisation. Despite the fact that they attain godhood, the "Prologue" and the "Epilogue" of some of these plays, unequivocally, predict that it is a "picture in this tragic glass" (Marlowe, 1940 , 7). That is, the protagonist has already been framed within a tragic structure, and thereby predestined to have a tragic end. One might view this predestination through the Foucauldian teleology. However, especially in Doctor Faustus, the place where the tragic end occurs is the most significant place (Greenblatt, 1980, p. 196).

It is interesting to note how Marlowe caters to different audience's demands. He attaches two prologues and appends two epilogues to The Jew of Malta. The "Prologue" 
spoken at the court, for the royal and noble audience, is meeker than the "Prologue" for the common audience. On the one hand, in the production for the court, Barabas, the Jew of Malta, has been clearly equated with Machiavelli and there is a humble request to "crown the action, and renown the pen" (Marlowe, 1965, 12). On the other, in the staging for the common audience, there is no such comparison and plea. What this version of the "Prologue" brings to notice is ambivalence towards the play's commercial success.

As far as the epilogues are concerned, the degree of meekness increases before the royal and noble audience. In the version for the common audience, it is stated that the actor "only aimed to go, but not outgo" (Marlowe, 1965, 4). In addition, the applause is expected. The explicitness shown in the "Prologue" and "Epilogue" of Doctor Faustus is completely different from other plays. The "Prologue" states that the protagonist with "waxen wings did mount above his reach, / And melting, heavens conspired his overthrow" (Marlowe, 1940, 21-2). Because he practised magic, or necromancy, "more than heavenly power permits" (Marlowe, 1940, 8).

Such prologues and epilogues arguably place the Marlovian heroes and plays on the Foucauldian teleological trajectory. That is, everything, especially the fate of the eponymous hero or the end of the play, is prefigured in front of the royal, noble or common audience. Even though the Marlovian heroes attain the godhood, they are predestined to doom. In this way, one might argue that the Marlovian heroes are enclosed and co-opted within and by the structure, convention, tradition or the world of the play itself. Whatever occurs in the world of Marlovian plays has already been permitted, that is, the Marlovian heroes have been authorised to transgress and deify or subjectivise themselves. The transgression and deification or subjectivisation are insignificant, because the Marlovian heroes will be chastised in the end in quasi-moralistic terms.

The fact of such developments reiterates the point of Marlowe that his heroes and plays are subjected to a reality that is outside the world of dramatics. This reality demands a teleological submission from the playwright and his protagonists. Christopher Marlowe, needless to say, does adhere to and abide by the teleological paradigm proposed and demanded by the first half of dyad. 
Acknowledgement: The author wishes to acknowledge Professor GJV Prasad who was the Supervisor on his MPhil dissertation "The Matrix of Power: A Critique of Marlovian Heroes", which was submitted to the Jawaharlal Nehru University, New Delhi, in 2008. This article is partly based on the dissertation. $\mathrm{He}$ is also indebted to Professor Saugata Bhaduri for introducing the author to the world of theories, especially, the Foucauldian notion of power between 2004 and 2006. Finally, the author would like to acknowledge Dr Miranda Das for reading the manuscript and suggesting some changes.

Peer-review: Externally peer-reviewed.

Conflict of Interest: The author has no conflict of interest to declare.

Grant Support: The author declared that this study has received no financial support.

\section{References}

Bataille, G. (2001). Eroticism (M. Dalwood, Trans.). London, UK: Penguin Books.

Comensoli, V. (1993). Homophobia and the regulation of desire: A psychoanalytic reading of Marlowe's Edward II. Journal of the History of Sexuality, 4(2), 175-200. https://www.jstor.org/stable/3704287

Dollimore, J. (2004). Radical tragedy: Religion, ideology and power in the drama of Shakespeare and his contemporaries. Hampshire, UK: Palgrave Macmillan.

Engle, L. (2013). Marlowe and the self. In E. C. Bartels \& E. Smith (Eds.), Christopher Marlowe in context (pp. 202211). Cambridge, UK: Cambridge University Press.

Foucault, M. (1988). The political technology of individuals. In L. H. Martin, H. Gutman \& P. H. Hutton (Eds.), Technologies of the self: A seminar with Michel Foucault (pp. 145-162). Amherst, USA: University of Massachusetts Press.

Foucault, M. (1990). The Use of Pleasure. Volume 2 of The History of Sexuality (R. Hurley, Trans.). New York, USA: Vintage Books.

Foucault, M. (2003). Abnormal: Lectures at the Collège de France 1974-1975 (G. Burchell, Trans.). London, UK: Verso. Goldberg, D. (1992). Sacrifice in Marlowe's The Jew of Malta. Studies in English Literature, 1500-1900, 32(2), 233245. https://www.jstor.org/stable/450734

Greenblatt, S. (1980). Renaissance self-fashioning: From More to Shakespeare. Chicago, USA: University of Chicago Press.

Huebert, R. (2003). The performance of pleasure in English renaissance drama. Hampshire, UK: Palgrave Macmillan. Machiavelli, N. (1984). The Prince (P. Bondanella \& M. Musa, Trans.). Oxford, UK: Oxford University Press.

Marlowe, C. (1940). Tamburlaine the great I \& II. In J. Hampden (Ed.), Three plays. London, UK: Thomas Nelson \& Sons Ltd. Originally staged in 1587.

Marlowe, C. (1940). Doctor Faustus. In J. Hampden (Ed.), Three plays. London, UK: Thomas Nelson \& Sons Ltd. Originally staged in 1592.

Marlowe, C. (1965). The Jew of Malta. R. W. V. Fossen (Ed.). London, UK: Edward Arnold Publishers Ltd. Originally staged in 1590. 
Marlowe, C. (1981). Edward II. In F. Bowers (Ed.), The complete works of Christopher Marlowe. Cambridge, UK: Cambridge University Press. Originally staged in 1592.

Ribner, I. (1953). The idea of history in Marlowe's Tamburlaine. ELH, 20(4), 251-266. https://www.jstor.org/ stable/2871967

Schwarz, K. (2013). Marlowe and the question of will. In E. C. Bartels \& E. Smith (Eds.), Christopher Marlowe in Context (pp. 192-201). Cambridge, UK: Cambridge University Press. 